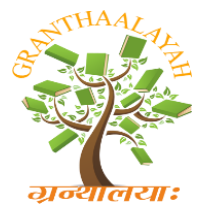
INTERNATIONAL JOURNAL OF RESEARCH GRANTHAALAYAH A knowledge Repository

Science

\title{
ALOE VERA: A MEDICINAL HERB
}

\author{
Dr. Shail Bala Sanghi ${ }^{* 1}$
}

${ }^{* 1}$ Department of Botany, Govt. M. L. B. P. G. Girls College, Bhopal, INDIA

\begin{abstract}
Aloe vera is a herb distributed all over the world. The herb is used internally to counter most of the problems of digestion, diabetes, immune system, and peptic ulcers. It also contains antibacterial, anti-septic, anti-viral, anti-inflammatory, anti-tumor, anti -oxidant, moisturizing, anti-aging effects. This review highlights the importance of using Aloe vera as a medicinal herb.
\end{abstract}

Keywords:

Aloe vera. Medicinal, Herb.

Cite This Article: Dr. Shail Bala Sanghi, “ALOE VERA: A MEDICINAL HERB” International Journal of Research - Granthaalayah, Vol. 3, No. 11(2015): 32-34.

\section{INTRODUCTION}

The name Aloe comes from the Arabic word alloeh meaning a shining bitter substancel. The botanical name of Aloe Vera is Aloe Barbadensis Miller. It belongs to the Liliaceae family, which has about 360 species. Aloe Vera is a cactus like plant that grows readily in hot and dry climate and currently, because of high demand, is cultivated in large quantities. It grows mainly in dry regions of Asia, Africa, America and Europe. In India, it is found in Maharashtra, Andhra Pradesh, Gujarat, Rajasthan and Tamil Nadu2. Cosmetics and some medicinal products are made from the mucilaginous tissue at the center of the Aloe vera leaf and are called Aloe Vera gel. This gel is a clear, tasteless, thin, jelly like material. The other part of the plant is a group of specialized cells known as the pericyclic tubules. They occur just beneath the outer green rind of the leaf. These cells produce exudates that consist of bitter yellow latex with powerful laxative-like action2. This plant has yellow flowers. The leaves, arranged in a rosette configuration are triangular and spear like and have thorny ridges.

\section{CHEMICAL CONSTITUENTS OF THE PLANT}

There are over 100 active biologic constituents found within aloe3. The plant is a rich source of natural, health -promoting substances: 
- Polysaccharides: Aloe gel is $99 \%$ of water with a $\mathrm{pH}$ of 4.5 and is a common ingredient in many non-prescription skin salves. The gel has an emollient polysaccharide, glucomannan. It is a good moisturizer, and is used in many cosmetics. Other poly saccharides such as arabinan, arabinorhamnogalactan, glactan, galactogalacturan, glucogalactomannan and glucuronic acid containing polysaccharides are isolated from the Aloe vera inner leaf gel part ${ }^{4}$.

- Anthraquinones /Anthrones: Aloe emodin, aloetic acid, anthranol, aloin A and B, isobarbaloin emodin ester of cinnamic acid are also found in Aloe vera.

- Vitamins/Minerals: It provides vitamin C, A, E, B, B Carotene, Zinc, Calcium, Copper, Magnesium, Manganese and phosphates.

- Enzymes: It contains alliase, alkaline phosphatase amylase catalase, lipase peroxidase and corboxy peptidase enzymes.

- Amino acids: It provides 20 of the 22 human required amino acids and 7 of the 8 essential amino acids.

- Plant sterols: 4 plants steroids campestrol, cholesterol, bsitosterol and lupeol.

\section{THERAPEUTIC USES OF ALOE VERA}

The Aloe vera exudates are transparent, slippery mucilage or gel given by the thin walled tubular cells in the inner central zone (parenchyma) of the leaf. This mucilage was applied to inflamed skin and during the 20th century, it was helpful for radiation burns. The bioactive compounds are used as astringent, homeostatic, antidiabetic, antiseptic, antibacterial, antioxidant and anti-tumor agents and also effective in treating stomach ailments, gastrointestinal problems, constipation, radiation injury, wound healing, burns, dysentery, diarrhea and treatment of skin diseases. Currently the plant is widely used in skin care ${ }^{5}$.

Aloe vera has 75 potentially active constituents, vitamins, enzymes, minerals, sugar, lignin, saponin, salicylic acid and amino acids.

- Anti-oxidant activity: It contains vitamin A, B Carotene, C and E. They are anti-oxidants. It provides calcium, magnesium, potassium, sodium, and zinc minerals which are essential for the proper functioning of various enzymes which are antioxidants.

- Wound healing: Cumulative evidence supports the use of Aloe Vera for the healing of first to second degree burns6. The wound healing properties of Aloe Vera gel has been attributed to mannose-6 phosphate7. Brady kinase enzymes help in the reduction of excessive inflammation, when applied to the skin topically.

- Anti-ulcer activity: A number of glycoproteins present in Aloe vera gel have anti-tumor and anti-ulcer effects8.

- Anti-bacterial and anti-viral activity: Aloe vera gel provides 12 anthraquinones which are phenolic compounds traditionally known as laxatives. Aloin and Emodin acts as analgesics, antibacterials and antivirals 9 .

- Anti-septic and analgesic properties: Aloe vera gel provides some fatty acids like cholesterol, campesterol, B-sisosterol and lupesol. All of them have anti-inflammatory action and lupesol also possess antiseptic and analgesic properties ${ }^{10}$.

- Other medicinal uses: Traditionally, Aloe vera gel is used both topically (treatment of wounds, burns, and skin irritations) and internally to treat constipation, ulcers, diabetes, 
headache, arthritis, immune system deficiency ${ }^{11}$. Aloe vera contains polysaccharides which increase the insulin level and show hypo glycemic properties ${ }^{12}$.

- Cosmetics and skin protection application: Aloin and its gel are used as skin tonic for pimples. Aloe vera is also used for soothing the skin and keeping the skin moist to help avoid flaky scalp and skin in harsh and dry weather ${ }^{13}$. Aloe vera show laxative effect due to presence of anthraquinone. It has also been reported to have moisturizing and anti-aging effect along with anti-septic and anti-diabetic effects ${ }^{12}$.

\section{CONCLUSION}

In late years, ethno -botanical and traditional uses of natural compounds, especially of the plant origin receive much attention as they are well tested for their efficacy and generally believed to be safe for human use. Many Indian herbs are being used in traditional practices to cure various human ailments. Aloe vera, has an important place among such wound healing medicinal plants it can also be used in treating many diseases and use as cosmetics products also. Furthermore property of Aloe vera has also made a better understanding of its use as a potential drug in addition to contemporary drugs further research should be encouraged to utilize the herbs with medicinal properties.

\section{REFERENCES}

[1] Ghazanfar S.A. Hand book of Arabian medicinal plants .Boca Rato; CRC Press, 1994.

[2] Richard L.W. Aloe vera gel: Update for dentistry. Pharmacology Today.2005;6-9

[3] Ronald M. S., Aloe vera; its chemical and therapeutic properties. Int J Dermatol.

[4] Choi S., Chung M.H., A review on the relation - ship between Aloe vera components and their Biologic effects. Semin Integr Med (2003) ;1:53-62

[5] Shelton R M. Aloe vera Its chemical and therapeutic properties. Int. J Dermatol, 1991; 30; 679-83.

[6] Maenthaisong R., Chaiyakunapruk N. and Niruntra S., The Efficacy of Aloe vera for Burn Wound Healing: A Systematic Review Burns (2007) 33 (6) : 713-718.

[7] Davis,R.H., Donato,J.J. Hartman,G.M.and Hass,R.C. ,Anti-Inflammatory and Wound Healing Activity of a Growth Substance in Aloe vera. Journal of the American Podiatric Medical Association (1994) 84 (2):77-81.

[8] Sai Krishna Borra, Radha Krishna Lagisetty and Gowrinath Reddy Mallela. 2011 .African Journal of Pharmacy and Pharmacology vol.5, pp.1867-1871.

[9] Lawrence R, Tripathi P, Jeyakumar E. Isolation, Purification and Evaluation of Antibacterial Agents from Aloe vera. Journal of Microbiology. 2009,40:906-15.

[10] Barcroft and Myskja Aloe vera; Nature'S Silent Healer,BAAM (2003)

[11] Tanaka,M.et al., Identification of Five Phytosterols from Aloe vera Gel as Anti-diabetic Compounds. Biological and pharmaceutical Bulletin, 29 (7):1418-1422.

[12] Eshun, K. and He, Q., Aloe vera: A Valuable Ingredient for the Food, Pharmaceutical and Cosmetic Industries-A Review. Critical Reviews in Food Science and Nutrition (2004) 44 (2):91-96.

[13] West D.P. and Zhu Y.F., Evaluation of Aloe vera Gel Gloves in the Treatment of Dry Skin Associated with Occupational Exposure. Am. J. Infect Con (2003), 31(1):40-42. 